Int. J. Electrochem. Sci., 12 (2017) 9689 - 9696

\title{
Gadolinium Doped Strontium Cerate Prepared by Citric- Nitrate Auto-Combustion Process and Intermediate Temperature Electrical Properties of Its Composite Electrolyte
}

\author{
Lin Sun, Hongtao Wang ${ }^{*}$, Liangquan Sheng, Huiquan $\mathrm{Li}^{* *}$ \\ School of Chemical and Material Engineering, Fuyang Normal College; Anhui Provincial Key \\ Laboratory for Degradation and Monitoring of Pollution of the Environment, Fuyang 236037, China \\ *E-mail: hongtaoking3@163.com, huiquanli0908@163.com
}

doi: $10.20964 / 2017.10 .37$

Received: 24 June 2017 / Accepted: 2 August 2017 / Published: 12 September 2017

In this work, $\mathrm{SrCe}_{0.9} \mathrm{Gd}_{0.1} \mathrm{O}_{3-\alpha}$ electrolyte was prepared by a citric-nitrate auto-combustion (CNA) method using $\mathrm{Gd}_{2} \mathrm{O}_{3}, \mathrm{HNO}_{3}, \mathrm{Sr}\left(\mathrm{NO}_{3}\right)_{2},\left(\mathrm{NH}_{4}\right)_{2} \mathrm{Ce}\left(\mathrm{NO}_{3}\right)_{6}$ and citric acid as raw materials and subsequently compounded with $\mathrm{NaCl} / \mathrm{KCl}$. The XRD results have shown that no reactions between $\mathrm{SrCe}_{0.9} \mathrm{Gd}_{0.1} \mathrm{O}_{3-\alpha}$ and $\mathrm{NaCl} / \mathrm{KCl}$ have took place. The SEM examinations reveal that the particle size of $\mathrm{SrCe}_{0.9} \mathrm{Gd}_{0.1} \mathrm{O}_{3-\alpha}$ is uniform, and the surface is uniformly covered by $\mathrm{NaCl} / \mathrm{KCl}$ that acts as the $\mathrm{SrCe}_{0.9} \mathrm{Gd}_{0.1} \mathrm{O}_{3-\alpha}$ particle binder. The ionic and protonic conduction of $\mathrm{SrCe}_{0.9} \mathrm{Gd}_{0.1} \mathrm{O}_{3-\alpha}$ (SCGd-CNA) was studied by using gas concentration cells. The fuel cell based on $\mathrm{SrCe}_{0.9} \mathrm{Gd}_{0.1} \mathrm{O}_{3-\alpha}-\mathrm{NaCl}-\mathrm{KCl}$ (SCGd-CNA-NK) exhibits excellent cell performance with a maximum power output density of 215 $\mathrm{mW} \cdot \mathrm{cm}^{-2}$ at $700{ }^{\circ} \mathrm{C}$, which is much higher than for single cerium strontium material, SCGd-CNA, i.e. $20.7 \mathrm{~mW} \cdot \mathrm{cm}^{-2}$ at $700{ }^{\circ} \mathrm{C}$.

Keywords: Composite; Electrolyte; Fuel cell; $\mathrm{SrCeO}_{3}$; Conductivity

\section{$\underline{\text { FULL TEXT }}$}

(C) 2017 The Authors. Published by ESG (www.electrochemsci.org). This article is an open access article distributed under the terms and conditions of the Creative Commons Attribution license (http://creativecommons.org/licenses/by/4.0/). 